\title{
Putting Theory into Practice: James Black, Receptor Theory and the Development of the Beta-Blockers at ICI, 1958-1978
}

\author{
VIVIANE QUIRKE*
}

\begin{abstract}
Introduction
The concept of drug receptors has played a significant role in the biomedical sciences and in pharmaceutical innovation in the second half of the twentieth century. Although the concept dates back to the work of the German bacteriologist and immunologist Paul Ehrlich and of the British physiologist John Newport Langley at the end of the nineteenth and the beginning of the twentieth century, its acceptance was delayed because of conflicting ideas about drug action, and because of uncertainties and hesitations about the concept itself. ${ }^{1}$

As a consequence of such conflicts and hesitations, the concept remained highly speculative, and its application was delayed. According to Andreas-Holger Maehle, Cay-Rüdiger Prüll and Robert Halliwell: "it was not until Raymond P. Ahlquist (1914-1983) made his famous distinction, in 1948, between $\alpha$ - and $\beta$-adrenoceptors, that receptor research began to provide a powerful basis for pharmaceutical innovation". ${ }^{2}$ One of the key events in the establishment and acceptance of the concept of receptor was the introduction in 1965 of propranolol as "the first clinically useful beta-receptor blocker", 3 for which James (now Sir James) Black was awarded the Nobel Prize in $1988 .{ }^{4}$
\end{abstract}

(C) Viviane Quirke 2006

*Viviane Quirke, DPhil, Centre for Health, Medicine and Society, Tonge Building, Oxford Brookes University, Oxford OX3 OBP, UK.

I am grateful to Professor Sir James Black for his comments on an earlier version of this paper, and to AstraZeneca for permission to publish it. The help of Dr Desmond Fitzgerald, who provided me with additional reading material and useful insights, as well as the comments of three anonymous referees, were invaluable. The research for this paper was carried out with funding from the Wellcome Trust.

\footnotetext{
${ }^{1}$ See J Parascandola, 'Origins of receptor theory', Trends Pharmacol. Sci., 1980, 1: 189-92; idem, 'The development of receptor theory', in M J Parnham and J Bruinvels (eds), Discoveries in pharmacology, vol. 3, Pharmacological methods, receptors and

chemotherapy, Amsterdam, Elsevier, 1986, pp. 129-56. On the development of the receptor concept by
}

Paul Ehrlich, see C-R Prüll, 'Part of a scientific master plan? Paul Ehrlich and the origins of his receptor concept', Med. Hist., 2003, 47: 332-56; on John Langley's role in the elaboration of receptor theory, see A-H Maehle, “"Receptive substances": John Newport Langley (1852-1925) and his path to a receptor theory of drug action', Med. Hist., 2004, 48: 153-74.

${ }^{2}$ A-H Maehle, C-R Prüll and R F Halliwell, 'The emergence of the drug receptor theory', Nature Reviews, Aug. 2002, 1: 637-41, on p. 641. See also C-R Prüll, A-H Maehle, and R F Halliwell, 'Drugs and cells-pioneering the concept of receptors',

Pharmacy in History, 2003, 45: 18-30.

${ }^{3}$ See the time line in Maehle, et al., op. cit., note 2 above, p. 638.

${ }^{4}$ On Black, see V P Gerskowitch, R A D Hull, and N P Shankley, 'The "pharmacological toolmaker's" rational approach to drug design: an appreciation of Sir James Black', Trends Pharmacol. Sci., 1988, 9: 435-7. See also V Quirke, 'Black, James Whyte', Encyclopedia of life sciences, 20 vols, London, Nature Publications Group, 2002, vol. 3, pp. 300-1. 


\section{Viviane Quirke}

\section{Table 1}

ICI's Beta-Blockers

- 1963: launch of Alderlin (compound 38,174, or pronethalol)

- 1965: launch of Inderal (compound 45,520, or propranolol)

- 1970: launch of Eraldin (compound 50,172, or practolol)

- 1976: launch of Tenormin (compound 66,082, or atenolol)

Black himself has emphasized the link between Ahlquist's theory of two receptors, propranolol, and the investigations that followed the drug's discovery:

Now there is no doubt that [Ahlquist's] theory of two receptors had a powerful influence in directing the studies of clinical investigators once suitable agents, such as propranolol, became available. There is equally no doubt that my own work begun in 1958, to find a way of reducing myocardial demand for oxygen in hearts whose oxygen supply was restricted by arterial disease, would not have been started but for the existence of Ahlquist's theory. ${ }^{5}$

In fact, propranolol (also known under its trade name Inderal) replaced pronethalol (Alderlin), which was the first clinically useful beta-blocker (see Table 1). Like propranolol, pronethalol had been developed by Black at Alderley Park, Imperial Chemical Industries' (ICI) pharmaceutical research centre in Cheshire, south of Manchester. ${ }^{6}$ However, unlike pronethalol, which was withdrawn from the market because it was found to cause thymic tumours in mice, propranolol became a best-selling drug, used for the treatment of a wide range of cardiovascular diseases, from angina pectoris to hypertension, a success attributable to ICI's research and development (R\&D) and commercial strategy as well as to Black's inventiveness and skill. As such, propranolol was to play an important part in the acceptance of the receptor concept in scientific circles, and in the use of receptor theory as a tool for pharmaceutical innovation.

The main focus of this paper is on the development of receptor theory and its impact on the $R \& D$ programme of the company which discovered the first clinically useful betablockers: ICI's Pharmaceutical Division, where it came to play an important part in rational drug design, an aspect largely overlooked by histories of receptor theory and of the betablockers. Not only does this paper aim to fill an important gap in the historiography, but it provides fresh insights on the roles of the individual scientist, James Black, who brought Ahlquist's dual receptor theory with him when he moved to Alderley Park, and the industrial research team, who applied it, turning it into a new class of drugs.

As well as published sources, I have used the research reports of ICI, which-although by no means exhaustive-are the principal archival resource currently accessible on the subject. I have consulted these reports, written twice a year by the different project leaders

\footnotetext{
${ }^{5} \mathrm{~J}$ W Black, 'Ahlquist and the development of beta-adrenoceptor antagonists', Postgrad. med. J., 1976, 52, Suppl. 4: B I Hoffbrand, R G Shanks, and I Brick (eds), Ten years of propranolol: a symposium
}

on the history and future of beta-blockade, (Amsterdam, 26-28 Sept. 1975): 11-13, on p. 11.

${ }^{6} \mathrm{C}$ Kennedy, ICI: the company that changed our lives, London, Hutchinson, 1986, pp. 136-41. 
James Black, Receptor Theory and the Development of Beta-Blockers at ICI

for presentation of progress and results to ICI's research managers, for the period before Black's arrival, during his presence at Alderley Park, and after his departure for Smith, Kline \& French's UK laboratory in Welwyn Garden City.

When Black arrived at Alderley Park in 1958, a cardiovascular research programme had begun to take shape there, and Black's original approach to the problem of angina pectoris benefited from the company's growing experience with cardiovascular drugs. ${ }^{7}$ Thus, I begin with a brief history of ICI's Pharmaceutical Division and the origins of its cardiovascular programme.

\section{ICI's Cardiovascular Research Programme before Black (1954-1958)}

ICI had been created in 1926 from the merger between the four largest companies in the British chemical industry: Brunner, Mond \& Co. Ltd, Nobel Industries Ltd, the United Alkali Co. Ltd, and the British Dyestuffs Corporation Ltd. ${ }^{8}$ It was within the Dyestuffs Group (renamed Division in 1944) laboratories at Blackley, north of Manchester, that ICI first began to carry out pharmaceutical research. This happened in 1936, after Gerhard Domagk, whose work in the laboratories of the German firm Bayer was modelled on Paul Ehrlich's research on the therapeutic uses of dyestuffs, had found that the red dye Prontosil possessed antibacterial activity. ${ }^{9}$ At the Pasteur Institute in Paris, Ernest Fourneau and his team discovered that the active part of the molecule was the colourless substance sulphanilamide, which had long been known and therefore could not be covered by patents. ${ }^{10}$ This discovery prompted the decision to set up a Medicinal Chemicals Section within the Dyestuffs Group of ICI, a decision that was encouraged by the company's academic advisors, who included Carl Browning (Professor of Bacteriology at Glasgow University). ${ }^{11}$ At first compounds were sent for testing to researchers in medical school laboratories, whose work was co-ordinated by a panel of biological as well as chemical consultants. However, in 1937 ICI began recruiting biologists to work at Blackley as part of a multidisciplinary team. ${ }^{12}$

As soon as the war broke out, ICI moved into the production of synthetic drugs formerly imported from Germany, particularly the anti-malarials Mepacrine and Pamaquin, equivalent to "Atebrine" and "Plasmochin". ${ }^{13}$ They also became involved in the production of penicillin, developing the first industrial process for manufacturing the drug by surface culture. ${ }^{14}$ In 1942, the group became key partners in two crucial wartime Anglo-American

\footnotetext{
${ }^{7}$ For a more detailed analysis of the origins of ICI's cardiovascular research programme, see V Quirke, 'From evidence to market: Alfred Spinks' 1953 survey of new fields for pharmacological research, and the origins of ICI's cardiovascular programme', in V Berridge and K Loughlin (eds), Medicine, the market, and the mass media: producing health in the twentieth century, London, Routledge, 2005, pp. 144-69.

${ }^{8} \mathrm{~W}$ J Reader, Imperial Chemical Industries: $a$ history, 2 vols, London, Oxford University Press, 1975, vol. 2, pp. 3, 13.

${ }^{9}$ See J Lesch, 'Chemistry and biomedicine in an industrial setting: the invention of the sulfa drugs',
}

in S H Mauskopf (ed.), Chemical sciences in the modern world, Philadelphia, University of Pennsylvania Press, 1993, pp. 158-215.

${ }^{10} \mathrm{D}$ Bovet, Une Chimie qui guérit: histoire de la découverte des sulfamides, Paris, Payot, 1988.

${ }^{11}$ Kennedy, op. cit., note 6 above, pp. $120-1$.

${ }^{12} \mathrm{~K}$ Holland, 'IC Pharmaceuticals', Pharmaceutical Journal, Sept. 1987, 12: 286-8. See also C W Suckling and B W Langley, 'Francis Leslie Rose, 1909-1988', Bio. Mem. F.R.S., 1990, 36: 491-524, on p. 498.

${ }^{13}$ Reader, op. cit., note 8 above, vol. 2, p. 286.

${ }^{14}$ Ibid. 


\section{Viviane Quirke}

pharmaceutical research programmes: the first to develop novel synthetic anti-malarials, in a project that culminated in the discovery of ICI's Paludrine and Winthrop's Chloroquine, and the second to produce penicillin on a large scale and find a synthetic route to its manufacture. ${ }^{15}$ In 1942, the profits made from sulphonamide and anti-malarial drugs led to the creation of a selling company devoted to pharmaceuticals, IC (Pharmaceuticals) Ltd, and the founding of a veterinary business. ${ }^{16}$ In 1944, recognizing the growing importance of pharmaceuticals within Dyestuffs, ICI's main board formed a separate Pharmaceutical Division. $^{17}$

The experience gained in synthesizing, testing and manufacturing anti-malarials was to have a considerable impact on ICI's pharmaceutical R\&D after the war. Not only did it provide the company, for a time at least, with profits to invest back into pharmaceutical research, but it also provided ICI's scientists with chemical leads for synthesizing new drugs. In particular, clinical observations of the hypotensive side-effects of certain antimalarials provided leads for novel anti-hypertensive agents. ${ }^{18}$ However, at ICI this only happened once hypertension had been adopted as a research topic.

ICI's cardiovascular programme developed gradually after the acknowledgement in 1948, at the second meeting of the Pharmaceutical Division's newly-formed Chemotherapeutic Research Committee, that of all chronic afflictions hypertension was the most serious. ${ }^{19}$ Because of the potentially large numbers of patients involved, estimated by the Committee at 90 per cent of the population over the age of fifty in so-called "civilized" countries, ${ }^{20}$ it was therefore considered worthy of the company's attention. However, because its cause was uncertain, and it was difficult to reproduce in the laboratory, it was also recognized as requiring a "speculative" approach, that is to say a theoretical approach to drug development, based on scientific hypotheses, in contrast with more routine chemical investigations. ${ }^{21}$

In 1951, hypertension was put forward as a new research target, ${ }^{22}$ but it did not become an actual research topic, within a wider programme to study diseases of "organic dysfunction", 23 until 1954, when a new pharmacological section was established at Blackley. As well as hypertension, this section included the study of diuretics, anticoagulants, local anaesthetics, pancreatic function, inflammatory conditions, and gastric secretion. James Raventos, a biologist who had joined ICI's pharmaceutical laboratories in 1938, worked on the last topic. ${ }^{24}$ Alfred Spinks, an ICI chemist, who in 1950 had been sent to Oxford

\footnotetext{
${ }^{15}$ Kennedy, op. cit., note 6 above, pp. 127-9.

${ }^{16}$ Holland, op. cit., note 12 above, vol. 2, p. 286.

${ }^{17}$ Reader, op. cit., note 8 above, vol. 2, p. 459;

Kennedy, op. cit., note 6 above, p. 129.

${ }^{18} \mathrm{~J}$ A Woodbridge, 'Social aspects of pharmaceutical innovation: heart disease', PhD thesis, University of Aston, Birmingham, 1981, p. 26.

${ }^{19}$ AstraZeneca ICI research report (hereafter ICI)

CPR 3: minutes of 2nd meeting of the

Chemotherapeutic Research Committee, 31 March

1948. ICI records are held at Alderley Park, Cheshire.

${ }^{20}$ Ibid., minutes of meeting, 24 Sept. 1951.

${ }^{21}$ Ibid., minutes of 1st meeting, 19 Jan. 1948.

A member of the committee, Dr J Madinaveitia, for example, drew the Committee's attention to the

"importance of biochemical work as a basis for
}

new ideas and new lines of synthetic work".

However, pharmacology rather than biochemistry was to provide ICI with their first angle of approach to the problem of hypertension.

${ }_{22}^{2}$ Ibid., minutes of meeting, 19 July 1951.

${ }^{23}$ The term "diseases of organic dysfunction", rather than the now more familiar "chronic diseases", was used at ICI to distinguish their study from that of infectious diseases. ICI CPR 33: Research Department, Biological Group (Diseases of Organic Dysfunction) Report, Oct.-Dec. 1954.

${ }^{24}$ ICI CPR 3: 31 March 1953; ICI CPR 8: 1 Dec. 1954; ICI CPR 11: joint plan for 1954. On Raventos, see D G Davey, 'Dr James Raventos', obituary, Br. J. Pharmacol., 1983, 80: 3. 


\section{James Black, Receptor Theory and the Development of Beta-Blockers at ICI}

University to acquire training in the biological sciences, and on his return to Blackley designed and led the pharmacological section, took the largest share of the programme. ${ }^{25}$ Assisted by the chemist E H P Young and the technicians Brian Horsfall and D Dunlop, he worked on hypertension, diuretics, anticoagulants, local anaesthetics, and sedatives. In 1955, the section was augmented by a new unit, on atherosclerosis, led by the biochemist $\mathrm{J}$ M Thorp, who went on to discover the hypolipidemic actions of clofibrate. ${ }^{26}$

When ICI's new pharmaceutical research centre, Alderley Park, opened in 1957, ICI had therefore been working on topics related to heart disease for three years. Spinks' research on hypertension led to the ganglion-blocker pempidine, launched in 1958 under the name Tenormal. ${ }^{27}$ These drugs, which were quaternary ammonium derivatives, were widely used for the treatment of hypertension in the UK in the 1950s. However, they were poorly absorbed orally and caused side-effects, including postural hypotension and constipation. Consequently, when Black arrived at Alderley Park in 1958, ICI were preparing to alter their approach to the problem of hypertension, and start looking at central, rather than peripherally-acting agents. ${ }^{28}$ By 1959, the title of the series of research reports on "Anaemia, allergy, rheumatism, and cardio-vascular diseases" reveals that a proper cardiovascular programme was in place at ICI. ${ }^{29}$

Not only did Black find in ICI an organization with an interest and expertise in heart disease, but Ahlquist's dual receptor theory, which he would apply there in order to devise a new way of treating angina pectoris, was beginning to gain acceptance among scientific circles. Here follows a short summary of the history of receptor theory before Ahlquist.

\section{Receptor Theory before Ahlquist (c. 1900-1948)}

The roles of Ehrlich and Langley in the formulation of receptor theory at the end of the nineteenth and beginning of the twentieth century has been examined in depth. ${ }^{30}$ However, according to the historian of pharmacology John Parascandola, it was largely through A J Clark's quantitative work on the interaction between drugs and receptors in cells in the 1920 s and 1930s that the theory began to spread among pharmacologists. ${ }^{31}$ Clark had

\footnotetext{
${ }^{25}$ A W Johnson, F L Rose and C W Suckling, 'Alfred Spinks, 1917-1982', Bio. Mem. F.R.S., 1984, 30: 567-94.

${ }^{26}$ ICI CPR 35: Research Report of the Biological Group (Pharmacological Section) for July-Dec. 1955. J M Thorp, 'An experimental approach to the problem of disordered lipid metabolism', J. Atheroscler. Res., 1963, 3: 351-60.

${ }^{27}$ Johnson, et al., op. cit., note 25 above, p. 584.

${ }^{28} \mathrm{R}$ Vos, Drugs looking for diseases: innovative drug research and the development of the beta-blockers and the calcium antagonists, Dordrecht, Kluwer Academic, 1991, pp. 81-2. This comment is based on an interview with Black.

${ }^{29}$ ICI CPR 50, 50/3: Research Department Period Report, 22 Jan. 1959.
}

\footnotetext{
${ }^{30}$ Prüll, op. cit., note 1 above; also Maehle, op. cit., note 1 above.

${ }^{31}$ Parascandola, 'The development of receptor theory', op. cit., note 1 above, pp. 150-3; idem, 'A J Clark: quantitative pharmacology and the receptor theory', Trends Pharmacol. Sci., 1982, 3: 421-3. On Clark, see also Prüll, et al., op. cit., note 2 above, pp. 26-7. For an indirect view of the development and gradual acceptance of receptor theory, see A Albert's series of textbooks on Selective toxicity. It is interesting to note that it was not until Albert became more confident in the scientific basis of receptor theory, in the 3rd edition of the series published in 1965, that he began to appreciate the role played by Clark. A Albert, Selective toxicity, 3rd ed., London, Methuen, 1965, pp. 45-7.
} 


\section{Viviane Quirke}

trained in physiology at Cambridge University at the time when Langley was elaborating his theory of receptive substances in 1903-7. ${ }^{32}$ Clark's interest in the subject was sparked off by Walter Dixon, who taught pharmacology there. In 1919, Clark moved to University College London, where he succeeded A R Cushny in the chair of pharmacology, and began work on the neurotransmitter acetylcholine. It was this research which led him to receptor theory. ${ }^{33}$ In 1926, Clark left for Edinburgh, where he occupied the chair of materia medica after Cushny's death. There he pursued his work on acetylcholine, showing in experiments with Raventos (this was before he joined ICI's pharmaceutical laboratories at Blackley) that the antagonism between acetylcholine and quaternary ammonium salts could be explained in terms of the drugs competing for a common receptor. ${ }^{34}$

Then, in 1933, Clark published The mode of action of drugs on cells, which was to have a considerable impact on the discipline of pharmacology. ${ }^{35}$ Using a mathematical approach to analyse a large amount of pharmacological data, Clark showed that for many drugs the relationship between drug concentration and biological effect corresponded to a hyperbolic curve, similar to that representing the adsorption of a gas onto a metal surface. From this, he concluded that the curve expressed the equilibrium between a drug interacting with a specific number of receptors on the cell, and that the pharmacological action produced by the drug was "directly proportional to the number of receptors occupied". "By the time Clark had developed his version of receptor theory, it fitted well with the 3-D picture of the cell that was being developed at the time. This may explain why it was this version which, in Parascandola's view, helped to establish the drug receptor concept in pharmacology. ${ }^{37}$

However, it was not until after the Second World War that it became an important focus for pharmacological research, for example in the work of E J Ariëns in Utrecht and R P Stephenson in Edinburgh, who modified Clark's occupancy theory to explain the affinity (i.e. the attraction between a compound and a receptor) and the efficacy (i.e. the ability of the drug-receptor complex to elicit a physiological response, or "intrinsic activity") of drugs. ${ }^{38}$ In addition, Stephenson introduced the concept of partial agonist, to signify a compound with high affinity but low efficacy, thereby making an important distinction between the affinity of a drug for a receptor, and its potency once attached, a concept that later became important in beta-blockade. ${ }^{39}$

At the same time as these theoretical developments were taking place, the institutional basis of pharmacology within universities and drug companies was expanding. Moreover, the fast increase in the numbers of structure-activity studies, made possible by technological developments and new insights in theoretical chemistry, meant that conceptualization

\footnotetext{
${ }^{32}$ On Clark's life and scientific career, see E V Verney and I Barcroft, 'Alfred Joseph Clark, 1885-1941', Obit. Not. F.R.S, 1939-41, 3: 969-84.

${ }^{33}$ Parascandola, 'The development of receptor theory', op. cit., note 1 above, pp. 149-50.

${ }^{34}$ A J Clark and J Raventos, 'The antagonism of acetylcholine and of quaternary ammonium salts', Q.J.Exp.Phys., 1937, 26: 375-92. See also Verney and Barcroft, op. cit., note 32 above, p. 974.

${ }^{35}$ Parascandola, 'A J Clark', op. cit., note 31 above, p. 422.
}

\footnotetext{
${ }^{36}$ Clark is quoted in Prüll, et al., op. cit., note 2 above, p. 27.

${ }^{37}$ Parascandola, 'The development of receptor theory', op. cit., note 1 above, p. 151; idem, 'A J Clark', op. cit., note 31 above, p. 422.

${ }^{38}$ E J Ariëns, 'Affinity and intrinsic activity in the theory of competitive inhibition', Arch. Int. Pharma. Théra., 1954, 99: 32-49; R P Stephenson, 'A modification of receptor theory', Brit. J. Pharmacol. Chemother., 1956, 11: 379-93.

${ }^{39}$ Woodbridge, op. cit., note 18 above, p. 137.
} 


\section{James Black, Receptor Theory and the Development of Beta-Blockers at ICI}

of the reactions between drugs and tissues in terms of receptors was gradually becoming more acceptable, and more deeply ingrained in laboratory practice. ${ }^{40}$

Thus, receptor theory emerged progressively from a variety of research fields, which included immunology, chemical work on metabolism, a mathematical approach to pharmacological data, and the physiology of the autonomic (sympathetic and parasympathetic) nervous system. ${ }^{41}$ In our story, the sympathetic nervous system (SNS) played a particularly important role, for the beta-blockers resulted from a cross-fertilization between research on the SNS on the one hand, and studies of the interactions between drug or hormone and cell on the other. ${ }^{42}$ The idea of drug-receptor interaction had been developed early on in connection with the SNS by Langley, although he did not use the word "receptor", introduced in 1900 by Ehrlich in the context of his immunological research, but rather "receptive substance". ${ }^{43}$ Thus, he had argued that certain drugs, like the suprarenal extract adrenaline, which produce an effect similar to electrical stimulation of the sympathetic nerves, bound to receptive substances in cells and that there were two types of such substances, "motor" (excitatory) and "inhibitory". ${ }^{44}$ His results were soon confirmed by Henry Dale, who showed that while the excitatory actions (i.e. vasoconstriction and contraction of smooth muscle) of adrenaline and other structurally similar compounds in most tissues were blocked by ergot alkaloids, their inhibitory effects (i.e. vasodilation and relaxation of bronchial muscle in the lungs) were not. ${ }^{45}$ However, Dale, who became a hugely influential figure in British medicine generally, and pharmacology in particular, ${ }^{46}$ like other researchers remained sceptical about Langley's idea that drugs combined with specific receptive substances or "side-chains", and subsequently failed to give his full support to the concept of receptor. ${ }^{47}$ Thus, it is through a later interaction between research on the SNS and receptor theory that the concept of beta-blockade eventually emerged. ${ }^{48}$ This happened after the publication of Ahlquist's seminal paper in 1948.

\section{Ahlquist's Dual Receptor Theory before the Beta-Blockers (1948-1960)}

Ahlquist's paper had begun as an investigation into the ability of sympathomimetic amines (i.e. compounds like adrenaline that "mimic" stimulation of the SNS-a term coined by George Barger and Dale in $1910^{49}$ ) to reduce the tone of uterine muscle in order to alleviate period pains. Having carried out a comparative study of a series of these compounds, Ahlquist found that the responses to them in a variety of tissues existed in

\footnotetext{
${ }^{40}$ Ibid., pp. 127, 135-6. See also A Albert, Selective toxicity, 5th ed., London, Methuen, 1973, p. 220.

${ }^{41}$ Prüll, et al., op. cit., note 2 above, p. 27.

${ }^{42}$ Woodbridge, op. cit., note 18 above, p. 115

${ }^{43}$ Maehle, op. cit., note 1 above, p. 173.

${ }^{44} \mathrm{~J}$ N Langley, 'On the reaction of cells and of nerve-endings to certain poisons, chiefly as regards the reaction of striated muscle to nicotine and to curari', J. Physiol., 1905, 33: 374-413.

${ }^{45} \mathrm{H}$ H Dale, 'On some physiological actions of ergot', J. Physiol., 1906, 34: 163-206.

${ }^{46}$ See W F Bynum, An early history of the British Pharmacological Society, 1931-1981, London, British
}

Pharmacological Society, 1981, pp. 8-9. By the time of the Second World War, Dale's leadership in science administration meant that he was himself no longer closely involved in scientific research.

${ }^{47}$ Maehle, op. cit., note 1 above, p. 171. See also a later article by Dale on 'Pharmacology and nerve-endings', Proc. R. S. Med., 1935, 28: 319-32, on p. 319 .

${ }^{48}$ Woodbridge, op. cit., note 18 above, p. 115

${ }^{49} \mathrm{G}$ Barger and H H Dale, 'Chemical structure and sympathomimetic action of amines', J. Physiol., 1910-1911, 41: 19-59. 


\section{Viviane Quirke}

two orders of potency. These results led him to question whether adrenergic receptors (the receptors at which the neurotransmitter passes on messages from sympathetic nerves) could be classified simply as either excitatory or inhibitory, and to conclude that there existed two distinct types of adrenergic receptors, which he named alpha and beta. ${ }^{50}$ Thus, stimulation of alpha-receptors resulted in excitatory responses such as vasoconstriction and contraction of smooth muscle in a variety of tissues, whereas stimulation of beta-receptors led to inhibitory responses such as vasodilation, and bronchial and uterine muscle relaxation. However, Ahlquist had also observed in the case of the heart, which he studied as an isolated part of the cardiovascular system, that excitatory responses such as the increase in rate and force of contraction corresponded to the beta-receptors and not the alpha-receptors as in other tissues. ${ }^{51}$

Ahlquist's findings helped to explain the anomalous pharmacological properties of isoprenaline (a $\beta$-agonist), which did not provoke vasoconstriction, pressor response (a rise in blood pressure), or cause decongestion, as might have been expected of a sympathomimetic amine, but on the contrary produced vasodilation, depressor response and tachycardia, a fact that had long puzzled pharmacologists. Furthermore, his results went some way to clarify the actions of the known sympatholytics (i.e. compounds that oppose the effects of stimulation of the SNS) as " $\alpha$-blocking agents" ${ }^{52}$ In time, Ahlquist's dual receptor theory became a paradigm for the experimental study of adrenergic receptors and the development of adrenergic drugs, and provided a model for the pharmacological and physiological study of the SNS. ${ }^{53}$

However, according to Black, this was a paper before its time. ${ }^{54}$ It was rejected for publication by the Journal of Pharmacology and Experimental Therapeutics because of objections made against its methodology, and because its central tenet, that adrenaline was the principal neurotransmitter, had been disproved in 1946 by Ulf S von Euler who had shown that it was, in fact, noradrenaline. ${ }^{55}$ It was published finally in 1948 thanks to Ahlquist's friend and colleague W F Hamilton, editor of the American Journal of Physiology. Nevertheless, it was largely ignored for about ten years, until 1958, the year in which Black began his work at Alderley Park. Black has explained this ten year gap by arguing that Ahlquist's paper had remained hidden "in the long shadows cast by two giants-H.H. Dale in England, and W.B. Cannon in the USA". Dale, in particular, although he came close to thinking in terms of receptors, "never gave receptor theory the benefit of his huge scientific support", and consequently his attitude "seems to have had a powerful effect in delaying the introduction of the idea of receptors into pharmacological teaching and his impact was still dominant when Ahlquist's paper appeared in $1948 ", 56$

\footnotetext{
${ }^{50} \mathrm{R}$ P Ahlquist, 'A study of the adrenotropic receptors', Am. J. Phys., 1948, 153: 586-600; Idem, 'Adrenergic receptors: a personal and practical view', Perspect. Biol. Med., 1973, 17: 119-22.

${ }^{51}$ Vos, op. cit., note 28 above, pp. 71-2.

${ }^{52}$ Ahlquist, 'Adrenergic receptors', op. cit., note 50 above, p. 120 .
}

\footnotetext{
${ }^{53}$ Vos, op. cit., note 28 above, pp. 72, 76.

${ }^{54}$ Kennedy, op. cit., note 6 above, p. 137.

${ }^{55}$ Vos, op. cit., note 28 above, p. 75. Also

G O Carrier, 'Evolution of the dual adrenergic receptor concept: key to past mysteries and modern therapy', in Parnham and Bruinvels (eds), op. cit., note 1 above, pp. 203-21, on pp. 217-18.

${ }^{56}$ See Black, op. cit., note 5 above, p. 12.
} 


\section{James Black, Receptor Theory and the Development of Beta-Blockers at ICI}

Cannon's influence, on the other hand, had imprinted the minds of generations of biologists with images of a system beautifully adapted to survival. In his theories there was little room for the idea that the activity of the sympathetic nervous system might not always have survival value. To account for its deleterious effects, Cannon came up with a theory (described by Black as "a baroque theory" 57 ) of two sympathins E and I, which was the accepted doctrine at the time of Ahlquist's paper. Although von Euler's research had already begun to erode the factual basis of Cannon's sympathin theory and, in 1949, A M Lands commented in the first volume of the journal Pharmacological Reviews that the concept of sympathins $\mathrm{E}$ and I as mediators of adrenergic nerve impulses seemed to have outlived its usefulness, it remained none the less widely accepted as a conceptual framework, which delayed the acceptance of Ahlquist's dual receptor theory. ${ }^{58}$

Then, in 1958, came C E Powell and I H Slater's description of the pharmacological properties of Eli Lilly's new compound dichloroisoproterenol (DCI), which according to Black "provided the turning point and [led to] the rapid acceptance of the idea of a dual receptor mechanism". ${ }^{59}$ DCI was an analogue of isoprenaline, which had been synthesized by the Eli Lilly group with a view to exploiting isoprenaline's bronchodilator properties, but which intrigued them by antagonizing its effects on the heart. However, although they described DCI's properties in terms of Ariëns' and Stephenson's concepts of affinity and intrinsic activity, Powell and Slater did not refer to Ahlquist's work in their article. ${ }^{60}$ Published by the Journal of Pharmacology and Experimental Therapeutics (ironically perhaps, after the editorial board's rejection of Ahlquist's 1948 paper), it was followed six months later by another by N Moran and M E Perkins in the same journal, in which they argued that DCI's activity belonged to Ahlquist's "beta-adrenergic" type, and coined the term "beta-adrenergic blocking drug", later shortened to "beta-blocker". 61

In his book Drugs looking for diseases, Rein Vos has argued that Moran and Perkins' recognition of DCI as the exemplar of a new class of bio-active compound (the first betablocker in fact) did not occur by chance, but rather that it was the result of a complex process of disciplinary transformation which affected both pharmacologists and clinical scientists. ${ }^{62}$ However, as Desmond Fitzgerald has shown, there was an important element of chance in this, for Moran had been studying the cardiovascular effects of different catecholamines (substances which act mainly as neurotransmitters on the sympathetic and central nervous systems) when he happened to hear Powell and Slater's paper. ${ }^{63}$ Chance

\footnotetext{
${ }^{57}$ Ibid.

${ }^{58} \mathrm{U}$ S von Euler, 'A specific sympathomimetic ergone in adrenergic nerve fibres (sympathin) and its relations to adrenaline and nor-adrenaline', Acta. Physiol. Scand., 1946, 12: 73-97; A M Lands, 'The pharmacological activity of epinephrine and related dihydroxyphenylalkylamines', Pharmacol. Rev., 1949, 1: 279-309, on p. 301.

${ }^{59}$ Black, op. cit., note 5 above, p. 12.

${ }^{60}$ See R A Maxwell and S B Eckhardt, Drug discovery: a casebook and analysis, Clifton, NJ, Humana Press, 1990, p. 13. Also A M Barrett, 'Design of $\beta$-blocking drugs', in E J Ariëns (ed.), Drug design, New York, Academic Press, 1972, vol. 3, pp. 205-28, on p. 208; R G Shanks, 'The discovery of beta adrenoceptor blocking drugs', in M J Parnham and
}

J Bruinvels (eds), Discoveries in pharmacology, vol. 2, Haemodynamics, hormones and inflammation, Amsterdam, Elsevier, 1984, pp. 38-72.

${ }^{61} \mathrm{C}$ E Powell and I H Slater, 'Blocking of inhibitory adrenergic receptors by a dichloro analog of isoproterenol', J. Pharm. exp. Ther., 1958, 122: 480-8; N C Moran and M E Perkins, 'Adrenergic blockade of the mammalian heart by a dichloro analogue of isoproterenol', J. Pharm. exp. Ther., 1958, 124: 223-37.

${ }^{62}$ Vos, op. cit., note 28 above, p. 77.

${ }^{63}$ J D Fitzgerald, 'Trails of Discovery 1): The importance of chance and the prepared mind in the discovery of the beta-blockers', Dialogues in Cardiovascular Medicine, 2000, 5: 172-6, p. 172. 


\section{Viviane Quirke}

also played a part in the next step, which led Black to pronethalol and then propranolol, for he had only just joined ICI's cardiovascular team when he read Moran's report and realized that it would be possible to synthesize an analogue of DCI ${ }^{64}$ He hoped that this analogue, unlike DCI, which showed a degree of stimulant activity and turned out to be a partial agonist, would be clinically useful. ${ }^{65}$

Therefore, if DCI is to be considered as the "departure compound", which eventually led to propranolol, ${ }^{66}$ then the finding that DCI selectively blocked beta-receptors has proved to be "one of the most significant advances in human pharmacotherapy". 67 It was Moran and Perkins who accomplished this, and in the words of the clinicians, J M Cruickshank and B N C Prichard, "the major contribution of Black was to appreciate the possible clinical value of developing compounds to inhibit the sympathetic nerves to the heart, and then to persuade, and then lead a team of scientists at ICI to translate the idea into reality". 68

As a physiologist with medical training, Black developed a clinical orientation a pure scientist might not have had, and this was to play a key role in his ability to translate Ahlquist's dual receptor theory from an academic to an industrial setting. ${ }^{69}$ Furthermore, unlike pharmacologists working on the SNS, he was unhindered by classic beliefs and the frustrating experiences in the field. ${ }^{70}$ In the next section, I describe briefly the path which took him from Glasgow University's Veterinary School, where he developed his ideas about beta-adrenergic receptor antagonists, to Alderley Park, where he realized them.

\section{James Black, from Glasgow to Alderley Park (1950-1958)}

Black studied medicine at St Andrews University in Scotland, where he graduated in 1946. He then joined the University's Physiology Department under Professor R C Garry, before accepting a lectureship at the King Edward VII College of Medicine in Singapore in 1947. On his return in 1950, a chance encounter in London with Garry led to him being introduced to the Director of the University of Glasgow Veterinary School, William Weipers, who offered him a post. In the School, Black built up a "state-of-the-art" physiological laboratory and encouraged colleagues to come and work with him, including the academic surgeons Adam Smith and George Smith. ${ }^{71}$ These collaborations would help to shape Black's future research programme. With Adam Smith, he began work on the effects of 5-hydroxytryptamine on histamine in the increase in gastric secretions, a topic he

\footnotetext{
${ }^{64}$ Kennedy, op. cit., note 6 above, p. 137.

${ }^{65} \mathrm{~J}$ W Black, 'Drugs from emasculated hormones: the principles of synoptic antagonism' (Nobel Lecture, Dec. 8 1988), in T Frängsmyr (ed.), Nobel lectures in physiology or medicine, 1981-1990, Singapore, World Scientific, 1993, pp. 418-39, on pp. 418-19; also $\mathrm{M}$ Weatherall, In search of a cure: a history of pharmaceutical discovery, Oxford University Press, 1990, pp. 240-1.

${ }^{66}$ See Maxwell and Eckhardt, op. cit., note 60 above, table 1, p. 12.

${ }^{67}$ Ibid., p. 13.

${ }^{68}$ J M Cruickshank and B N C Prichard, Beta-blockers in clinical practice, 2nd ed.,
}

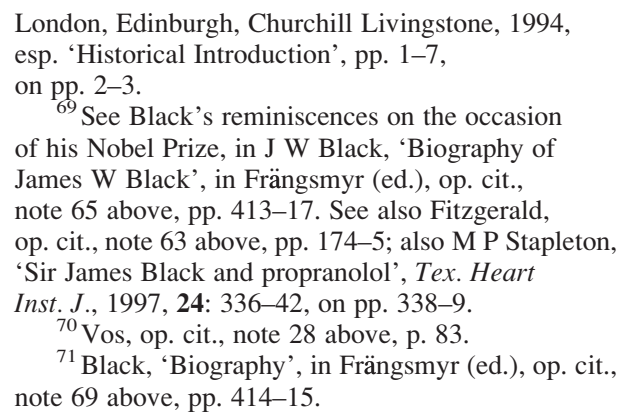

${ }^{69}$ See Black's reminiscences on the occasion of his Nobel Prize, in J W Black, 'Biography of James W Black', in Frängsmyr (ed.), op. cit., note 65 above, pp. 413-17. See also Fitzgerald, op. cit., note 63 above, pp. 174-5; also M P Stapleton, 'Sir James Black and propranolol', Tex. Heart Inst. J., 1997, 24: 336-42, on pp. 338-9.

${ }^{70}$ Vos, op. cit., note 28 above, p. 83.

${ }^{71}$ Black, 'Biography', in Frängsmyr (ed.), op. cit., note 69 above, pp. 414-15. 


\section{James Black, Receptor Theory and the Development of Beta-Blockers at ICI}

would return to in the 1960s in his search for compounds to block the histamine receptors in the gut. ${ }^{72}$ With George Smith, a professor of surgery from Aberdeen who had become familiar with American concepts and methods in cardiovascular physiology and surgery, and whose main interest lay in finding ways of increasing the supply of oxygen to the heart in patients with narrowed arteries, he also began work on the cardiovascular system. ${ }^{73}$

Black had personal as well as professional reasons for his interest in cardiovascular disease, more specifically angina pectoris. This is a painful illness, which occurs when the demand for blood by the heart exceeds the supply of the coronary arteries, leading to an increased heart rate and insufficient oxygenation of the heart. Black's father had suffered from it, and his death from a heart attack following a car crash had made Black ponder the role of stress in producing adrenaline, angina and heart attacks. ${ }^{74}$ Many of the drugs used to treat angina at the time were vasodilators, in particular nitrites, which increased the blood supply, and therefore the amount of oxygen to the heart, but which caused flushing of the face and headaches. ${ }^{75}$ Some time in the mid-1950s, ${ }^{76}$ Black "turned the problem on its head", and hypothesized that, instead of treating angina by increasing the supply of oxygen to the heart, it might be possible to do so by reducing the demand from the heart. ${ }^{77}$ Ahlquist's paper, which he first came across in a 1954 edition of Drill's Pharmacology, ${ }^{78}$ provided him with a solution, suggesting that it should be possible to block the receptors responsible for the increased heart rate. Thus, the "Beta-blocker project" was born in 1956, when Black started searching for substances antagonizing the effects of adrenaline and noradrenaline on the heart. ${ }^{79}$

In the course of this search, Black found that the commercial extract of bovine heart muscle Recosen, marketed by Robapharm in Switzerland for the treatment of angina, ${ }^{80}$ protected rabbits against the vasoconstrictor effect of pitressin, but also observed that this effect was exerted on the heart, not on the blood vessels. ${ }^{81}$ Urged on by a friend who was the local representative of ICI's Pharmaceutical Division, Black turned to them in the hope of obtaining a research grant. ${ }^{82}$ ICI had long-standing relationships with a number of Glasgow scientists, including Carl Browning, who retired in 1951, as well as with gastroenterologists and pharmacologists. ${ }^{83}$ Moreover, since the creation of their veterinary business in 1942, ICI had contacts with the Veterinary College and Hospital. ${ }^{84}$ A visit

\footnotetext{
${ }^{72}$ K H George, 'James Black, English pharmacologist', in E J McMurray (ed.), Notable twentieth-century scientists, 4 vols, New York, Gale Research, 1995, vol. 1, pp. 185-7, on p. 185. George was obviously unaware that Black is Scottish, not English. See also Black, 'Drugs from emasculated hormones', in Frängsmyr (ed.), op. cit., note 65 above, p. 425.

${ }^{73}$ Black, 'Biography', op. cit., note 69 above, pp. 414-15. Also Vos, op. cit., note 28 above, p. 82.

${ }^{74}$ Kennedy, op. cit., note 6 above, p. 136.

${ }^{75}$ Weatherall, op. cit., note 65 above, p. 31 . Vos, op. cit., note 28 above, pp. 78, 186.

${ }^{76}$ Shanks, in a personal communication to Maxwell and Eckhardt, op. cit., note 60 above, p. 13.

${ }^{77}$ Gerskowitch, et al., op. cit., note 4 above, p. 435.

${ }^{78}$ Kennedy, op. cit., note 6 above, p. 137; Stapleton, op. cit., note 69 above, p. 339.
}

\footnotetext{
${ }^{79}$ Gerskowitch, et al., op. cit., note 4 above, p. 435.

${ }^{80}$ Fitzgerald, op. cit., note 63 above, p. 172.

${ }^{81}$ Black published his results in 1959. J W Black, 'Electrocardiographic changes produced in rabbits by vasopressin (pitressin) and their alteration by prolonged treatment with a commercial heart extract', J. Pharm. Pharmacol., 1960, 12: 87-94; he also mentioned this research in his first report for ICI. ICI CPR 50: Research Department Report 50/3, 22 Jan. 1959.

${ }^{82}$ Black, 'Biography', Frängsmyr (ed.), op. cit., note 69 above, p. 415 , and personal communication.

${ }^{83}$ ICI CPR 1: 8 Jul. 1951; ICI CPR 3: 31 March 1948.

${ }^{84}$ See Holland, op. cit., note 12 above, p. 286; also ICI CPR 2: Development Memo for Oct. 1957: visit of Veterinary Services Department to Glasgow Veterinary College and Hospital, 12 Nov. 1957.
} 


\section{Viviane Quirke}

to Glasgow was therefore promptly arranged, and Garnet Davey, who was about to become head of biological research at ICI, met Black. Learning of his project he offered him a position, which Black, having heard "about this fairytale place ICI were building at Alderley Park", accepted. ${ }^{85}$ For this project, which was unusual and somewhat controversial at the time, Black would benefit not only from Davey's, but also from Spinks' support. $^{86}$

\section{Black, Receptor Theory, and DCI (1958-1960)}

Thus, in 1958, Black began working on ICI's coronary artery and hypertension projects, taking over the biological aspects of two of the main cardiovascular areas under study at Alderley Park. In his research, he was assisted by Brian Horsfall, a technician who had worked with Spinks on hypertension (see above), and whom Black encouraged to set up an instrumentation section in his laboratories. ${ }^{87}$ The chemical side was left to ICI's team of organic chemists, which included J S Stephenson, who had recently joined ICI, and then E H P Young, who like Horsfall had previously worked with Spinks on hypertension. For the purpose of this paper, I will concentrate on coronary artery disease, within which the beta-blocker project developed, and which soon overshadowed hypertension, until the two projects finally separated in 1974.

Trawling through the literature, Black and Stephenson found a paper in Comptes Rendus which claimed that it was possible to make adrenaline antagonists "par doublement de la molécule" ("by doubling up the molecule"). ${ }^{88}$ Thus picking up where Ernest Fourneau and Daniel Bovet had left off in the 1930s, they began searching for similar compounds. ${ }^{89}$ However, this approach was put in question by the arrival of Powell and Slater's, and Moran and Perkin's papers on DCI at the beginning of 1959.

Black realized the significance of DCI, especially it seems after Moran and Perkins had described its action in terms of beta-receptors. ${ }^{90}$ DCI, a sample of which had been synthesized by Stephenson, was therefore tried in the Langerdorff preparation-the isolated, spontaneously beating, guinea-pig heart. However, in this preparation, DCI showed stimulant activities similar to those of isoprenaline. Hence, Black designed a new in vitro

\footnotetext{
${ }^{85}$ Kennedy, op. cit., note 6 above, pp. 136-7.

${ }^{86}$ Johnson, et al., op. cit., note 25 above, p. 585 .

${ }^{87}$ The importance of Horsfall's contribution was later recognized by having a new section, called the Biological Electronics Unit, created for him in the Biology/Biochemistry Department. ICI DO772: Administration Section organization chart, 18 March 1971.

${ }^{88}$ Woodbridge, op. cit., note 18 above, p. 154 (based on an interview with Black). In 1933, Fourneau synthesized piperoxane, the first of a new class of adrenergic blockers (ibid., p. 143). Although the article in Comptes Rendus was not cited by Woodbridge, it is likely that it was E Fourneau and D Bovet, 'Recherches sur l'action sympatholytique
}

\begin{abstract}
de nouveaux dérivés du dioxane', $C$. $r$. Soc. biol. fil., 1933, 113: 388-90.

${ }^{89}$ Vos, op. cit., note 28 above, p. 84. The Swedish company A B Hässle, which merged first into Astra, and then with ICI's Pharmaceutical Division to form AstraZeneca, also picked up in 1963 the trail left by Fourneau, but unlike ICI did not abandon it (ibid., p. 110). More intriguingly still, in 1915 Fourneau had described the synthesis of phenoxypropanolamines, one of which was later synthesized by ICI and shown to be a beta-blocker. However, back in 1915, the effects of these compounds on the heart was thought to preclude them from being useful in the clinic. See Fitzgerald, op. cit., note 63 above, p. 174.

${ }^{90}$ Black, 'Drugs from emasculated hormones', op. cit., note 65 above, p. 420.
\end{abstract}




\section{James Black, Receptor Theory and the Development of Beta-Blockers at ICI}

assay, the rate-controlled isolated papillary muscle test. On the strength of this test, which made it possible to separate the effects of compounds on heart rate from those on force of contraction, and in which DCI showed no stimulant activity, Black became convinced that DCI was indeed the lead they had been looking for. ${ }^{91}$

Black's first research report, dated 22 January 1959, represented a clear departure for the cardiovascular research team. We contrast this with an earlier report by W S Waring in 1956 on the problem of atherosclerosis with Black's in 1959. Waring had approached the problem of atherosclerosis in terms of an indirect attack on cholesterol synthesis:

Working on the hypothesis that a high level of blood cholesterol is a predisposing factor in the development of atherosclerosis and coronary thrombosis, attempts are being made to devise compounds which will interfere with the biochemical mechanisms of cholesterol synthesis in the body and thus reduce the level of cholesterol in the blood. ${ }^{92}$

By contrast, Black analysed the same problem in terms of the underlying mechanism of coronary artery disease: "One possibility, scarcely tested, is that altered fat metabolism with associated changes in blood coagulability interact, permissively, with sympathetic neurohumoural stress responses to produce fatal damage". 93

From his hypothesis on the role of SNS, he derived a direct therapeutic approach to what he termed the "deleterious stress responses" leading to cardiovascular disease. The following paragraphs show Black linking his earlier work with bovine heart muscle extract, DCI, and the beta-receptors of the heart, and deriving from the latter the means to implement his approach:

It has been shown ([by] J. W. B.) that a commercial extract of bovine heart muscle, given to rabbits for a fortnight, protected the rabbit hearts against the coronary vasoconstrictor effects of pitressin. Pharmacological testing of this extract showed the presence of anti-adrenalin activity with respect to heart muscle but not with respect to blood vessels. A previous report from Sweden described an unknown sympatholytic factor in cardiac muscle, ineffective against the pressor action of adrenalin but active against the inhibitory effects of adrenalin in fowl caecum ...

There are two clearly differentiated sympathetic receptors $-\alpha$ receptors associated with excitatory effects on blood vessels and smooth muscle and $\beta$ receptors associated with inhibitory effects on smooth muscle and possibly cardiac muscle. All the known adrenolytic agents are $\alpha$ receptor inhibitors. Presumably the unknown factor in heart muscle is a $\beta$ receptor inhibitor and recently, the dichloro analogue of isoprenaline has been shown to be a powerful $\beta$ receptor inhibitor. The question of whether the latter compound will effectively block the cardiac sympathetic responses remains to be satisfactorily answered.

It seems clear that the search for compounds which will block cardiac sympathetic responses constitutes a clear-cut pharmacological problem and screening tests are being developed. In addition, experiments are planned which will attempt to elucidate further the possible value of such compounds in coronary artery disease. ${ }^{94}$

\footnotetext{
${ }^{91}$ Ibid., pp. 420-2. See also J W Black, 'A personal view of pharmacology', Annu. Rev. Pharmacol. Toxicol., 1996, 36: 1-33, on pp. 2-3.

${ }^{92}$ ICI CPR 26, ICI Pharmaceuticals Division Joint Report of Organic and Biochemical Sections (1954-7): 1 Jan.-31 March 1956.
}

${ }^{93}$ ICI CPR 50: 50/3, 22 Jan. 1959.
${ }^{94}$ Ibid. 


\section{Viviane Quirke}

In pursuit of his clear-cut pharmacological problem and therapeutic goal, Black devised a series of screening tests on isolated tissue preparations and whole animals. After DCI had been selected as their lead compound, the ICI team used a chemical structure-activity approach in order to improve on DCI. In January 1960, reasoning that a second phenyl ring might enhance the inhibitory activity of DCI, Stephenson replaced the two chlorine atoms in DCI by another phenyl ring, to make a naphthalene. ${ }^{95}$ This search for increased inhibitory activity would remain a constant in the group's subsequent work with the betablockers.

\section{From Pronethalol (Alderlin) to Propranolol (Inderal) (1960-1965)}

The new compound synthesized by Stephenson in 1960 was 38,174 (pronethalol, launched in 1963 under the name Alderlin after Alderley Park). It was found to be at least as active as DCI in the papillary muscle test. Further tests showed that "both drugs are specific beta-receptor blockers, that DCI is slightly more sympathomimetic than 38,174 , that DCI is slightly less active than $38,174 " .{ }^{96}$ However, although he considered 38,174 to be a highly promising lead, Black did not feel that the compound was ready as yet for clinical trial. More work needed to be done on its toxicity before its suitability for trial could be assessed.

In the meantime, in May 1960, a patent had been applied for, and Stephenson, who left ICI around then, was replaced by A F Crowther, who directed the chemical work, while $\mathrm{R}$ Howe and L H Smith completed the patent work as well as structure-activity studies, for which a large number of analogues were synthesized. ${ }^{97}$ The team grew from three in 1960 to thirteen by the end of 1963. Although most of the additional staff were chemists, early in 1962 ICI advertised for another cardiovascular specialist to work with Black. The person they appointed had already had experience with beta-blocking compounds. He was R G Shanks, who, after taking a BSc in physiology followed by a medical degree at Belfast University, had spent a year with Ahlquist at the University of Georgia. ${ }^{98}$ The team working on the beta-blockers now comprised Black, Shanks, Horsfall, and Dunlop, another ICI lab technician who had many years' experience in cardiovascular disease. ${ }^{99}$

A M Barrett, a pharmacologist who joined ICI's beta-blocker project in $1964,{ }^{100}$ has written that there are two reasons why synthesis of allied compounds continues even when a preferred compound — as was the case with pronethalol—is discovered: "(a) protection of the patent situation, and (b) protection of the market against the introduction of a better compound by a competitor". ${ }^{101}$ Between June 1961 and January 1962, 136 analogues synthesized as part of the patent completion work were tested for structure-activity relationships, and Black searched among them for a compound that could improve on 38,174 , i.e. "(a) be longer acting; (b) have greater resistance to catecholamine 'breakthrough';

\footnotetext{
${ }^{95}$ Barrett, op. cit., note 60 above, p. 213.

${ }^{96}$ ICI CPR 50/6: 14 June 1960.

${ }^{97}$ Vos, op. cit., note 28 above, p. 85.

${ }^{98}$ Woodbridge, op. cit., note 18 above, p. 176.

${ }^{99}$ Ibid., pp. 158, 177. Although he had been at ICI for longer, Dunlop's name first appeared in connection
}

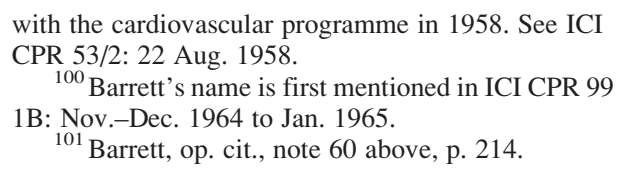




\section{James Black, Receptor Theory and the Development of Beta-Blockers at ICI}

(c) show less penetration of the CNS". ${ }^{102}$ However, by January 1962, no compound superior to 38,174 had yet been found.

As small-scale trials had begun in 1961, a biochemistry section was added to the already existing pharmacology and chemistry sections of the cardiovascular programme. New tests were performed by W A M Duncan, using a spectrofluorometric method to estimate the presence of pronethalol in blood and tissues. ${ }^{103}$ Six months later, as part of the structureactivity studies, Howe had discovered that in compounds which showed optical activity (i.e. the ability to rotate the plane of polarization of a beam of polarized light passed through a solution), the beta-blocking activity was confined to the left-handed isomer only. Although in itself not an unusual finding, Howe expressed it in terms of receptors, and, as far as my evidence shows, this was the first time that structure-activity relationships were described in this way at ICI:

The difference in biological activity between the members of a pair of racemes may be due to the effect of a particular spatial arrangement at the $\beta$ centre of asymmetry on the interaction with a receptor, or to the effect ... of that centre of the interaction of the $-\mathrm{OH}$ group or $-\mathrm{NH}$ group with a receptor, or combinations thereof. ${ }^{104}$

This quote suggests that the concept of receptor had become a working tool for the ICI researchers within the framework of the structure-activity studies of pronethalol.

By November 1962, 269 compounds, almost all of which were naphthalene, phenyl or heterocyclic derivatives of pronethalol, had been tested. Black's goal, of finding a superior compound, still had not been achieved: "In these series ... we are dealing with a bandspread of activity which will make it easier for competitors but difficult for us to find the peak, the crème de la crème, of desirable properties". ${ }^{105}$ On the other hand, in the process of searching for such an ideal compound, a number of molecules with greater potency had been discovered. In the naphthalene series, 45,520 showed ten to twenty times greater activity than pronethalol. In addition, it showed a superior therapeutic ratio (an increased ratio between blocking and toxic doses) in man. Compound 45,520 (propranolol, Inderal) was, in fact, to become Alderlin's replacement.

However, for the time being Black's attention remained focused on pronethalol, and on its mechanism of action. Now that it could be compared with a number of similar compounds, its activity showed important implications for Ahlquist's theory:

Although an injection of isoprenaline produces intense cardiac stimulation (and increases cardiac output), the blood pressure falls because the compound also produces widespread dilation of blood vessels. Both the cardiac and vascular effects of isoprenaline are conventionally classified as $\beta$-receptor responses and it has been shown repeatedly that Alderlin can so completely block the actions of isoprenaline that it no longer produces any cardiovascular responses. However, recently, a number of compounds have been found which convert the usual depressor response of isoprenaline to a marked pressor response. The action of one of these compounds has been analysed. It was found that the compound was blocking the peripheral vasodilation of isoprenaline but failing to block the cardiac responses. Thus the increased cardiac output delivered to undilated vessels now produced a pressor response ... I think these results mean that one must be cautious

${ }^{102}$ ICI CPR 50/8: 21 Aug. 1961; ICI CPR 56/8: 26 Jan. 1962.

${ }^{103}$ ICI CPR 56/8: 26 Jan. 1962.
${ }^{104}$ ICI CPR 50/9: 7 Nov. 1962.

${ }^{105}$ ICI CPR 56/9: 7 Nov. 1962. 


\section{Viviane Quirke}

about turning Ahlquist's dual receptor theory of adrenergic mechanisms into a sacred cow... While there is no case for multiplying the number of postulated receptors (c.f. cholinergic receptors) there is a case against a too-ready acceptance of dual receptor theory. ${ }^{106}$ [My emphasis.]

Thus, in the course of his experiments, Black had begun to modify Ahlquist's dual receptor theory into something more complex, involving a greater number of receptor subdivisions. This suggested that it might be possible to develop compounds with even more selective blocking activity than pronethalol. Black became fascinated with this idea in relation to the treatment of peptic ulcers, with which he saw parallels with angina. ${ }^{107}$ ICI would explore the existence of further receptor subtypes later, in connection with the cardio-selective properties of practolol (Eraldin) and atenolol (Tenormin), the next important phase in their use of receptor theory as a tool for pharmaceutical innovation.

By April 1963, toxicity tests had shown that, whereas with pronethalol thymic tumours appeared in mice within 120 days, with 45,520 no tumours had appeared since the tests had begun in mid-December of the previous year. Nevertheless, Alderlin was launched in November 1963, after the series of small-scale clinical trials had shown it to be effective in angina and certain kinds of arrhythmias, although it was marketed primarily for conditions that were life-threatening. ${ }^{108}$ This rapid progress, from discovery (1960), to small-scale trials (1961), and to marketing (1963), was not only due to a fairly relaxed regulatory framework (this was before the 1962 thalidomide tragedy led to more stringent pre-launch regulations), but also to the fact that experience with ganglion-blockers in the 1950s had prepared the community of British cardiologists, with whom ICI developed close contacts, for the arrival of the beta-blockers. Symptomatic of this, was the rapid rise in interest amongst clinicians, with numbers increasing from four clinical centres investigating the beta-blockers in 1961, to forty-five in $1965 .^{109}$

At this point, although he continued to work briefly on hypertension, Black began to withdraw from the beta-blocker project, partly because of his lack of interest in the development stage the project had now entered, and partly because, by analogy with the betablockers, he was becoming captivated by the prospect of blocking the histamine receptors in the gut. ${ }^{110}$ Black failed to interest ICI in histamine, which by the early 1960 s had been abandoned in favour of gastrin (a hormone produced in the mucous membrane of the stomach and which stimulates the production of gastric juices). ${ }^{111}$ Therefore, he asked Edward Paget, who in 1963 had been recruited from ICI to head Smith, Kline \& French's (SK\&F) new R\&D department, for a job so that he could work on histamine's " $\beta$-receptors". 112

${ }^{106}$ ICI CPR 56/9: 7 Nov. 1962.

${ }^{107}$ The synthetic anti-histamines used at the time, such as mepyramine and diphenhydramine, did not inhibit the acid secretion stimulated by histamine, hence Black came up with the idea of finding a selective antagonist of histamine's "beta-receptors". See Gerskowitch, et al., op. cit., note 4 above, p. 436. NB: the first synthetic anti-histamines had in fact been developed by Daniel Bovet, working in Fourneau's laboratory in collaboration with Rhône-Poulenc. See V Quirke, 'War and change in the pharmaceutical industry: a comparative study of Britain and France in the twentieth century', special issue of Enterprise and History, 2004, 36: 64-83.

${ }^{108}$ Vos, op. cit., note 28 above, p. 85.

${ }^{109}$ Ibid., pp. 90-1, see also Vos's note 62, on p. 293.

${ }^{110}$ Woodbridge, op. cit., note 18 above, pp. 182-3.

${ }^{111}$ Ibid., p. 189.

${ }^{112}$ L Finucane, $S K \& F$ : from Camberwell to Welwyn Garden City, 1956-1989, Welwyn Garden City, Smith Kline \& French Laboratories Ltd., 1989, p. 49. Paget's name first appears in connection with ICI's cardiovascular programme in 1959. See ICI CPR 50/4: 16 June 1959. 


\section{James Black, Receptor Theory and the Development of Beta-Blockers at ICI}

The next section describes the development of beta-blockers after Black's departure. It shows how Black's influence on ICI's cardiovascular programme gradually faded, and was replaced by other influences in response to the new challenge posed by competitors' drugs. These provided a stimulus for investigations into further receptor subtypes, and once receptor proteins had been isolated in the 1970s, for fundamental research into the receptors themselves.

\section{From Propranolol (Inderal) to Practolol (Eraldin) (1965-1970)}

Shanks was now in charge of the pharmacological side of the beta-blocker and hypertension projects, assisted by W Rouse, Duncan (who was later also recruited by Paget at SK\&F), and Dunlop. ${ }^{113}$ The team sought a successor for Alderlin, and the different properties of propranolol were compared with those of other Alderlin analogues. Among these, the phenoxy analogue 45,763 was a clear favourite. However, it possessed some degree of sympathetic stimulant activity (Partial Agonist Activity-PAA, or intrinsic sympathomimetic activity-ISA as it came to be known), which had been Black's main reason for dropping DCI in favour of pronethalol. Therefore the team, on whom Black's influence could still be felt, chose 45,520 , i.e. propranolol. ${ }^{114}$

A trade name for propranolol was needed, and the near-anagram of Alderlin, Inderal, was selected. A new advisory body, the Committee on the Safety of Drugs (later re-named the Committee on Safety of Medicines (CSM) ) had just been created, and although in these early days propranolol could have been marketed without a CSM submission, ICI's Medical Department decided "as an exercise" to prepare one. ${ }^{115}$ For this, further toxicity and distribution studies were carried out. ${ }^{116}$

However, even before its launch, ICI was beginning to experience competition from other companies. Mead Johnson had recently developed the beta-receptor antagonist sotalol. Although less active than Inderal, it was also less toxic. Being very water soluble, it showed less penetration of the central nervous system (CNS) (which led to side-effects such as nightmares and hallucinations) and had a greater therapeutic ratio. ${ }^{117}$ This potential threat to Inderal led to the synthesis of further analogues, including 50,172 (practolol, Eraldin) which was to succeed, although never replace, Inderal-as well as further investigations of its properties. It is interesting to note that, as part of these studies, Inderal was tested for effects on histamine-induced gastric secretion rates by Dunlop. ${ }^{118}$

Clinical trials started in summer 1964, and a year later Inderal was launched, only twoand-a-half years after it had first been tested. ${ }^{119}$ The ground for Inderal had been well prepared by Alderlin. Clinicians took up study of the drug, and showed it to be effective not only in angina and arrhythmias, but later also in hypertension. Although it received little

${ }^{113}$ ICI CPR 56, 56/12: 24 Apr. 1964.

${ }^{114}$ Woodbridge, op. cit., note 18 above, pp. 191-3. On Black's enduring influence, see Vos, op. cit., note 28 above, p. 89.

${ }^{115}$ Woodbridge, op. cit., note 18 above, p. 193.

${ }^{116}$ ICI CPR 99, 2B: Feb.-Apr. 1965 ; CPR 99 3B: May-Aug. 1965.

\footnotetext{
${ }^{117}$ ICI CPR 56/12: 24 Apr. 1964 ; CPR 56/13:

13 Nov. 1964

${ }^{118}$ ICI CPR 56/13: 13 Nov. 1964.

${ }^{119}$ Kennedy, op. cit., note 6 above, p. 138; Vos, op. cit., note 28 above, p. 91 .
} 


\section{Viviane Quirke}

reaction at the time, the first paper on the use of propranolol as an antihypertensive drug by Brian Prichard, a clinical pharmacologist who took part in the early trials in angina at University College Hospital, has been seen retrospectively to have greatly influenced the clinical development of beta-blockade. ${ }^{120}$ There were some concerns about the safety of propranolol, which had been shown to be involved in some cases of cardiac failure. However, with enough positive evidence accumulating in its favour, ICI obtained clearance from the CSM to market Inderal in hypertension in January $1969 .{ }^{121}$ This event, followed in 1973 by the US Food and Drug Administration's (FDA) approval of Inderal as an antihypertensive agent, helped to establish the beta-blockers in general, and Inderal in particular in hypertension. ${ }^{122}$

In addition, the broad patent coverage secured by Crowther and his colleagues for propranolol consolidated ICI's foothold in the beta-blocker field, and limited the freedom of action of competitors to market compounds of their choice. ${ }^{123}$ Perhaps because of this, as well as the intrinsic merits of the drug, propranolol became the reference compound of what may be called the "second generation of $\beta$-adrenoceptor inhibitors", which may therefore be considered as "derivatives". ${ }^{124}$

Nevertheless, in response to growing competitive activity, ${ }^{125}$ and because Inderal had been found to cause bronchoconstriction in patients with asthma, in 1966 ICI's cardiovascular team turned to practolol, which had been shown not to block the bronchodilator action of isoprenaline:

50,172 is the first compound of which we know that produces this selective blockade. The importance of this finding is two-fold: it may be possible to obtain a compound (possibly 50,172) which will not block the beta-receptors in bronchial muscle; consequently this compound could be used in patients with reduced respiratory reserve not only for the treatment of angina, of cardiac arrhythmias, but in combination with a catecholamine bronchodilator to prevent the side-effects of cardiac stimulation. ${ }^{126}$

ICI's first priority, as it was defined by the pharmacologists, was the rapid choice of a nonsympathomimetic selective blocker for clinical trial. On the chemical side, the most important task was now "to continue the beta-blocker work until we have made, evaluated, selected and developed a preferred compound having each optimal activity pattern that we can postulate. We must energetically use our shrinking scientific lead to maintain our commercial lead" (my emphasis). ${ }^{127}$ One of the means of achieving this was to pool the scientific and technical capabilities available throughout ICI.

Thus, for the purpose of presenting structure-activity relations "on a more rational basis than hitherto", R H Davies of Management Services was asked to prepare a computer

${ }^{120}$ B N C Prichard and P M S Gillam, 'Use of propranolol in the treatment of hypertension', $\mathrm{Br}$. med. $J .$, 1964, ii: 725; Woodbridge, op. cit., note 18 above, p. 197. See also L Hansson, 'The use of propranolol in hypertension: a review', in Hoffbrand, et al., op. cit., note 5 above, pp. 77-80.

${ }^{121}$ Woodbridge, op. cit., note 18 above, pp. 212-13

${ }^{122}$ Ibid., p. 228.

\footnotetext{
${ }^{123}$ According to Barrett, this is actually an impediment to therapeutic progress. Barrett, op. cit., note 60 above, pp. 217, 226.

${ }^{124}$ Ibid., p. 217.

${ }^{125}$ Not only was there Mead Johnson's sotalol, A B Hässle's alprenolol, but also Ciba's oxprenolol, which were all launched around the same time. Woodbridge, op. cit., note 18 above, pp. 198-203, 214.

${ }^{126}$ ICI CPR 99, 5B: 25 May 1966.

${ }^{127}$ ICI CPR 99, 9B: 6 Nov. 1967.
} 


\section{James Black, Receptor Theory and the Development of Beta-Blockers at ICI}

programme based on information theory analysis, ${ }^{128}$ and assist the cardiovascular team in developing a reliable method of estimating cardiac beta-blockade and its effects on bronchial beta-receptors. Davies generated data on approximately 200 analogues of practolol, from which he expected to be able to locate the "receptor sites", for if rate of access proved to be the dominant factor in selectivity then "the inferences on receptor sites... were obvious". 129

Meanwhile, the pharmacologists pressed for practolol to be taken through to clinical study, which ICI's management, fearing renewed competition against Inderal, agreed to do. ${ }^{130}$ Shanks had left ICI in 1966, hence the development and marketing of practolol became A M Barrett's responsibility, with Desmond Fitzgerald, a clinical pharmacologist who joined ICI in 1967, helping to set up the clinical trials. ${ }^{131}$ Practolol was launched in 1970 under the name Eraldin.

Eraldin sold well, for the market for beta-blockers was now well established. However, by 1974 , it had been found to cause blindness in some patients, and ICI's then medical director, C C Downie, recommended its withdrawal if skin rashes and associated shrinkage of the conjunctiva appeared. A year later the CSM advised doctors about the dangers of practolol, which led to a sharp drop in prescribing. ICI set up a compensation scheme, for which the claims were to outnumber those for thalidomide by about 5 to 1 , even though in the end ICI did not pay out as much as they had originally budgeted for, as the exact cause of the adverse symptoms were sometimes difficult to ascertain. ${ }^{132}$ Nevertheless, these events precipitated the choice of a successor for Eraldin among the compounds that were then being subjected to a fundamental study of beta-blockade and beta-receptors.

\section{Atenolol (Tenormin), $\beta_{1}$ and $\beta_{2}$ Receptors, and Rational Drug Design (1970-1978)}

By 1975, when the decision was taken to withdraw Eraldin from the market, a number of candidate molecules, which were thought of as "insurance" over Eraldin, had already been identified. $^{133}$

They included 66,082 and 61,081. Both compounds seemed close enough to the "ideal beta-blocker" sought by the cardiovascular team. ${ }^{134} 66,082$ (atenolol, Tenormin), unlike propranolol, had no membrane-stabilizing action, which, it was thought at the time, might be linked to cardiac failure. ${ }^{135}$ Furthermore, unlike propranolol, it was water- rather than lipid-soluble, therefore it was expected to show less penetration of the CNS. In all these respects, compound 66,082 therefore appeared to be a "clean beta-blocker". ${ }^{136}$ However, whether selectivity was or was not a desirable property in a new beta-blocker reaching the market in the 1970s remained to be proved, therefore it was not clear which of 66,082 or 61,081 was preferable (see Table 2).

\footnotetext{
${ }^{128}$ On the role of computers and information science in drug design, see P J Lewi, 'Computer technology in drug design', in E J Ariëns (ed.), Drug Design, New York, Academic Press, 1976, vol. 7, pp. 209-75.

${ }^{129}$ ICI CPR 99, 13B: 27 March 1969.

${ }^{130}$ Woodbridge, op. cit., note 18 above, pp. 219-20.

${ }^{131}$ Fitzgerald joined ICI in 1967. See ICI CPR 99, 9B: 6 Nov. 1967.
}

\footnotetext{
${ }^{132}$ Woodbridge, op. cit., note 18 above, pp. 232-5.

${ }^{133}$ ICI CPR 99, 14B: 8 July 1969.

${ }^{134}$ ICI CPR 99, 13B: 27 March 1969.

${ }^{135}$ Membrane-stabilizing activity was later shown to be unimportant in beta-blockade. See Cruickshank and Prichard, op. cit., note 68 above, p. 7.

${ }^{136}$ Woodbridge, op. cit., note 18 above, pp. 254-5.
} 


\section{Viviane Quirke}

Table 2

Properties of Beta-Blocking Compounds

\begin{tabular}{lcllll}
\hline Compound & $\begin{array}{c}\mathrm{ED}_{50}^{\mathrm{a}} \\
(\mu \mathrm{g} / \mathrm{kg})\end{array}$ & Selectivity & $\begin{array}{c}\text { Local } \\
\text { anaesthesia }\end{array}$ & $\begin{array}{c}\text { Depressant } \\
\text { on heart }\end{array}$ & $\begin{array}{l}\text { Intrinsic } \\
\text { activity }\end{array}$ \\
\hline Inderal & 62 & No & Yes & Yes & No \\
Eraldin & 167 & Yes & No & No & Yes \\
Aptin & 80 & No & Yes & Yes & Yes \\
60,847 & 6 & Yes & No & No & Yes \\
66,082 & 96 & Yes & No & No & No \\
65,674 & 25 & Yes & Yes & Yes & Yes \\
61,081 & 112 & No & No & Yes & No \\
\hline
\end{tabular}

${ }^{\mathrm{a}}$ Effective dose for 50 per cent of the tests carried out. A lower number indicates a more potent compound.

Source: ICI CPR 99, 14B: 8 July 1969.

The recent restrictions brought about by the Medicines Act of 1968 concerning human use had made pre-clinical testing even more necessary than previously. ${ }^{137}$ For this reason, and to assist in the selection of the compound to succeed Eraldin, the potencies of the different drugs were compared. Greater potency (corresponding to a lower $\mathrm{ED}_{50}$, see Table 2) was now being described in terms of a "better receptor fit". ${ }^{138}$ In addition, quantitative and biochemical methods were adopted and modified to establish structure-activity relations, and to ascertain - at an ever increasing level of detail- the various properties of the compounds under study.

In 1969, the publication of an article in Nature describing Allen \& Hanburys specific beta-receptor stimulant AH 3365 (salbutamol, Ventolin) prompted the team to renew their focus on selectivity. ${ }^{139}$ Thus, the biochemist A R Somerville, working with H Tucker and J Coope of the Pharmaceutical Division's Chemistry Department, adapted the method developed by Robert Lefkowitz in Durham using affinity chromatography, ${ }^{140}$ in an effort to isolate the recently discovered beta-receptor protein. ${ }^{141}$ This, they hoped, would help them to "understand more fully the finer details of beta-receptor antagonism", including the nature of the beta-receptor itself, for the purpose of locating selective beta-blocker action. $^{142}$

Meanwhile, Davies' quantitative studies were nearing completion. ${ }^{143}$ They suggested that selectivity existed on account of slight changes in concentration attributable to phase

${ }^{137}$ Ibid., pp. 258.

${ }^{138}$ ICI CPR 99, 14B: 8 July 1969.

${ }^{139}$ ICI CPR 99, 14B: 8 July 1969. On the history of Ventolin, see E Jones, The business of medicine, London, Profile Books, 2001, pp. 330-3.

${ }^{140}$ A technique by which fixed ligands bind the receptors in a solution, preventing their flow through a chromatography column, with the effect of separating them from other materials. See J D Robinson, Mechanisms of synaptic transmission: bridging the gaps (1890-1990), Oxford University Press, 2001, p. 159.
${ }^{141}$ On the isolation of receptor protein from cell membranes, see ibid., pp. 157-63. Somerville found Lefkowitz's method difficult to reproduce, however.

${ }^{142}$ ICI CPR 99, 25B: 27 Feb. 1973.

${ }^{143}$ On the importance of quantitative-activity studies in the rise of a rational approach to drug design, see for instance Y C Martin, Quantitative drug design: a critical introduction, New York, Marcel Dekker, 1978. 


\section{James Black, Receptor Theory and the Development of Beta-Blockers at ICI}

differences immediately surrounding the receptors. ${ }^{144}$ These results were fed back into the cardiovascular research programme, and the hypothesis that "selectivity might reside in the micro-environment surrounding the receptor, rather than in the receptor itself" was tested in a variety of isolated tissue preparations. Because potency, as well as cardioselectivity, was desirable, Davies was also asked to re-evaluate quantitatively earlier data, which had previously been expressed only in qualitative terms. ${ }^{145}$ He did so using steadystate model equations based on an extension of the Hansch equations (which apply multiple linear regression to quantitative structure-activity relations or QSAR), ${ }^{146}$ considered to be the first of two possible approaches to the "design" of the ideal beta-blocker sought by the team (see (a) below). This ideal compound, it was now believed, might not only be a potent cardio-selective beta-blocking drug, but also a partial agonist, and therefore possess some degree of ISA after all. ${ }^{147}$ The second (see (b) below) consisted in the more traditional, empirical chemical method of drug development:

There are two possible approaches to obtaining the "ideal beta-blocker":

(a) using the Hansch-type analysis ... to find compounds of increasing potency in existing series (ureas and phenylhydrazones);

(b) extrapolating from current series into completely novel types. ${ }^{148}$

In the event, both methods were used, and the chemists set out to synthesize molecules which, on the basis of the hypothetical binding sites on the receptor, could adopt the requisite atomic spatial arrangements for binding to receptors. ${ }^{149}$ Were they to achieve this, it was anticipated that it would then be possible to compute an approximation for the optimum configuration for beta-receptor binding. ${ }^{150}$

Thus, within the context of ICI's beta-blocker programme, receptors were being transformed from hypothetical entities into tangible objects, which could be apprehended using a variety of scientific instruments, quantitative and biochemical methods, and be used to predict the properties of novel compounds and for drug design. ${ }^{151}$ The biochemical studies of the beta-receptor, in particular, gave substance to the idea of beta-receptor subtypes, and it was concluded "that there was a real difference in biochemical terms between $\beta_{1}$ and $\beta_{2}$ receptors". 152

${ }^{144}$ ICI CPR 99, 23B : 16 June 1972.

${ }^{145}$ ICI CPR 99, 22B: 7 March 1972.

${ }^{146}$ On Hansch's method see Martin, op. cit, note 143 above, and also A Verloop, 'The use of linear free energy parameters and other experimental constants in structure-activity studies', in Ariëns (ed.), op. cit., note 60 above, pp. 133-88.

${ }^{147}$ ICI CPR 99, 23B: 16 June 1972. Unlike

Black, Hässle's researchers believed that moderate beta-receptor stimulant action was useful in a beta-blocker, therefore it is likely that this change of position on ICI's part was a response to competitors' drugs coming onto the market. See Fitzgerald, op. cit., note 63 above, p. 174.

${ }^{148}$ ICI CPR 99, 23B: 16 June 1972.

${ }^{149}$ ICI CPR B 99, 30B: 23 Oct. 1974.
${ }^{150}$ ICI CPR B 99, 30B: 23 Oct. 1974.

${ }^{151}$ On this progress from hypothetical entity to tangible object see E J Ariëns, 'Receptors: from fiction to fact', Trends Pharmacol. Sci. inaugural issue, 1979, pp. 11-15; and R P Ahlquist, 'Adrenoceptors', in ibid., pp. 16-17.

${ }^{152}$ ICI CPR B 99, 33B: 20 Oct. 1975.

A M Lands had identified $\beta_{1}$ and $\beta_{2}$ receptors in 1967, concluding that while the former was prominent in cardiac stimulation, the latter played an important role in bronchodilation. A M Lands, et al., 'Differentiation of receptor systems activated by sympathomimetic amines', 1967, Nature, 214: 597-8. See Robinson, op. cit., note 140 above, p. 154. The first time $\beta_{1}$ and $\beta_{2}$ receptors were mentioned in ICI's research reports was in CPR 99, 27B: 22 Oct. 1973. 


\section{Viviane Quirke}

Furthermore, the beta-blockers themselves were becoming tools for isolating and characterizing the beta-receptor. Thus, ICI's chemists prepared a beta-blocker with a fluorescent probe attached for use as a tool in the investigation of the beta-receptor, for "it seemed reasonable to choose a beta-blocker (rather than any other compound) as a ligand in an attempt to isolate the beta-receptor protein". ${ }^{153}$ In 1976, ICI's cardioselective beta-blocker, atenolol, was compared with Allen and Hanburys' salbutamol, which acted selectively on the bronchial muscle, with a view not only to isolating and characterizing the beta-receptor, but also to confirming that there existed a difference in receptor type, and that phase distribution played a role in selectivity. ${ }^{154}$

Meanwhile, the quantitative study of the structure-activity relations of several series of beta-blockers had progressed, and it was now possible to plot ISA against a particular structural feature: the bulk of the ortho-substituent in the aromatic ring. The linearity of the plots suggested that they might be useful in the prediction of ISA in new molecules (which was particularly important for the selection of cardiotonics, on which the group had been working since 1964, in conjunction with the beta-blockers). ${ }^{155}$ The biochemical study of potencies and cardio-selectivity ratios of beta-blocking drugs, compared on isolated membrane systems from cardiac and uterus tissues and on isolated atrial and tracheal muscle preparations, enabled the researchers to articulate hypotheses concerning drug binding in the region of the receptor. In order to test these hypotheses, techniques were established for the measurement of binding to receptors, and it was hoped that they might offer a rapid method of characterizing receptor-binding units. Somerville was asked to consider whether these techniques, developed in connection with the beta-blockers, might not also be applied to the receptors associated with mucus secretion in the stomach. ${ }^{156}$ This request was almost certainly a reaction to Black's discovery of the first $\mathrm{H}_{2}$-receptor antagonist, cimetidine (Tagamet), at SK\&F. ${ }^{157}$

The withdrawal of Eraldin precipitated the choice of atenolol as ICI's next beta-blocker. It was launched in 1976 under the name Tenormin, reminiscent of ICI's ganglion-blocker Tenormal, as it was being marketed primarily as an antihypertensive. It became one of the best-selling heart drugs and, within ten years, Tenormin and its related products generated sales worldwide of about $£ 500$ million. Nearly 40 per cent of sales were made in the USA, 30 per cent in Western Europe (including the UK), 14 per cent in Japan, and 16 per cent in the rest of the world. ${ }^{158}$

\section{Conclusions}

By 1987, 36 per cent of the total value of the world's top twenty selling medicines was accounted for by $\mathrm{H}_{2}$ - and beta-blockers, and nearly 75 per cent of these sales were of products invented and developed in the UK. ${ }^{159}$ James Black played a crucial part in the development not only of the beta-blockers at ICI, but also of the $\mathrm{H}_{2}$-receptor antagonists at

\footnotetext{
${ }^{153}$ ICI CPR B 99, 30B: 23 Oct. 1974.

${ }^{154}$ ICI CPR B 99, 34B: 26 Feb. 1976.

${ }^{155}$ ICI CPR 99, 1B: Nov.-Dec. 1964 to Jan. 1965.

${ }^{156}$ ICI CPR B 99, 35B: July 1976.

${ }^{157}$ See Finucane, op. cit., note 112 above, ch.10. On the history of cimetidine, see also Maxwell and
} 


\section{James Black, Receptor Theory and the Development of Beta-Blockers at ICI}

SK\&F. In both instances, his research represented a point of departure for the two firms, and this gave them prime-mover status in their respective fields, as well as providing a lead for other companies to follow. ${ }^{160}$

However, the continuities provided by the industrial context in which he worked underpinned Black's research projects and, ultimately, their successful outcome. When Black arrived at Alderley Park in 1958, ICI had a budding cardiovascular programme, a team with expertise in cardiovascular disease, and were preparing to alter their approach after the launch of their ganglion-blocker pempidine. This provided Black with a fruitful framework for his research as well as colleagues with skills complementary to his own. Black himself has acknowledged that his "odyssey of painfully learning about pharmacology" began in 1958, when he joined ICI, and owed much to his colleagues there:

My years at I.C.I., between 1958-1964, were some of the most exciting of my life. I was assigned a brilliant chemist, John Stephenson. He taught me about modern deductive organic chemistry ... He converted me to pharmacology. Indeed, my whole experience at I.C.I. was an educational tour de force. I had to learn how to collaborate across disciplines, how to change gears when changing from research to development, how to make industry work-in short, how to be both effective and productive. ${ }^{161}$

As well as Stephenson, Black mentioned Crowther, Duncan, and Prichard. In addition, this paper has highlighted the role of laboratory technicians, who had a long-term experience of techniques and instruments in the cardiovascular field. Moreover, it has shown how, in the process of developing the beta-blockers, ICI built up distinctive pharmacological and biochemical capabilities, which were transferred to SK\&F when Paget became their head of R\&D in 1963, followed by Black and Duncan.

With these continuities provided by the industrial context, also came a rationale that is usually considered to be external to science. Whilst focusing on receptor theory as a tool for pharmaceutical innovation, I have alluded to the role of patenting, competitive activity, commercial strategy, and drug safety regulations in the history of the development of the beta-blockers. These aspects deserve to be more fully developed than they can be here, for while Black had helped to place ICI at the forefront of pharmaceutical innovation in the cardiovascular field, the firm's patenting, competitive and commercial strategies also contributed to their leading position on the market.

However, such continuities do not account for all aspects of the history of receptor theory and its applications. James Raventos, who had worked with Clark in Edinburgh in the 1930s, and joined ICI in 1938, was working on gastric secretions when Black arrived at Alderley Park. Had his chief interest not been the anaesthetic drug Fluothane, perhaps he would have gone on to develop histamine antagonists. ${ }^{162}$ Although more research needs to be done on the history of ICI's research programme into gastric secretions, the fact that they did not develop an $\mathrm{H}_{2}$-blocker like Tagamet suggests that, without Black, ICI's innovative capability in the cardiovascular field was not easily transferable to other therapeutic areas.

\footnotetext{
${ }^{160}$ On the parallels between the two projects, see Finucane, op. cit., note 112 above, p. 50.

${ }^{161}$ Black, 'Biography', op. cit., note 69 above, p. 415.
}

${ }^{162}$ Davey, op. cit., note 24 above. 


\section{Viviane Quirke}

One question therefore remains: had Black not gone to Alderley Park in 1958, would ICI still have developed beta-blockers? Because of their burgeoning cardiovascular programme, and because they were considering altering their approach at the time of Black's arrival, the answer is probably yes. However, it is also likely that the first beta-blockers would have been developed elsewhere, a couple of years later, in Sweden by A B Hässle, who, unlike others - such as Eli Lilly who had stumbled on beta-blocking compounds but failed to conceive of a use for them in the clinic-were looking for anti-arrhythmic drugs with beta-blocking properties. Therefore, without Black, ICI would almost certainly have been followers rather than leaders in the field.

In his article entitled 'Invention in the industrial research laboratory: individual act or collective process?', the historian of technology David Hounshell has argued that invention is at once individual and collective, and also at once discreet moment or act and continuous process. ${ }^{163}$ The history of the development of the beta-blockers at ICI not only reinforces this analysis, it enriches it by bringing in the respective roles of theory and practice in pharmaceutical innovation.

ICI's beta-blocker project was based on Ahlquist's dual receptor theory, which James Black translated from an academic to an industrial context when he came to work at ICI's research centre in Alderley Park. In ICI, Black found an organization with an interest and expertise in cardiovascular diseases, which provided him with a fruitful framework for his project to find compounds to block the beta-adrenoceptors of the heart, for the treatment of angina pectoris. The drugs that were the outcome of this programme, from propranolol to Tenormin, in turn helped to establish receptor theory among scientists and pharmaceutical companies, and in time became tools for investigating the nature and properties of betareceptors. Following the beta-blockers, Ahlquist's dual receptor theory was applied in pulmonary medicine, obstetrics, endocrinology, gastroenterology and psychiatry. Hence, the 1960s and 1970s, which followed Black's research at ICI, have become known as "the age of the receptor". ${ }^{164}$

${ }^{163} \mathrm{D}$ A Hounshell, 'Invention in the industrial research laboratory: individual act or collective process?', in R J Weber and D N Perkins, Inventive minds: creativity in technology, New York, Oxford University Press, 1992, pp. 273-90.
${ }^{164}$ See A W Cuthbert, 'Men, molecules and machines', Trends Pharmacol. Sci. inaugural issue (1979): 1-3, on p. 3. 